Illinois State University

ISU ReD: Research and eData

Theses and Dissertations

3-15-2016

\title{
Unpacking Empowerment Discourse Within a Women's Reentry Organization
}

Amanda Nicole Miller

Illinois State University, amiller10@alumni.uwosh.edu

Follow this and additional works at: https://ir.library.illinoisstate.edu/etd

Part of the Social and Cultural Anthropology Commons

\section{Recommended Citation}

Miller, Amanda Nicole, "Unpacking Empowerment Discourse Within a Women's Reentry Organization" (2016). Theses and Dissertations. 586.

https://ir.library.illinoisstate.edu/etd/586

This Thesis is brought to you for free and open access by ISU ReD: Research and eData. It has been accepted for inclusion in Theses and Dissertations by an authorized administrator of ISU ReD: Research and eData. For more information, please contact ISUReD@ilstu.edu. 


\section{UNPACKING EMPOWERMENT DISCOURSE WITHIN}

\section{A WOMEN'S REENTRY ORGANIZATION}

\section{Amanda N. Miller}

70 Pages

Through ethnographic research with a small organization, Jareth, that helps women transition from prison to the community, this work unpacks discourses of empowerment within reentry organizations. I argue that Jareth's empowerment discourse works on a personal and pragmatic level, but is weak against the structural arrangements that disfranchise women offenders. Empowerment does not critique businesses that do not want to employ former prisoners. It does not help the general public understand that prisons do not meet all of women's needs. I show that Jareth's empowerment discourse defines power and dependence in particular ways - through appropriate and inappropriate forms of power and dependence. Further, this "empowerment" discourse casts women as powerless victims, language that would be better aimed at the larger community than to the women themselves. Also, empowerment and practices of subjectification are linked together - Jareth's empowerment discourse reflects an important shift in the reconfiguration of governmental methods that gives women specific power, professionalism, which is expected to be used through self-regulation within the market. Strategies of empowerment then meet political goals of neoliberal governmentality. 
KEYWORDS: Empowerment, Gender, Prison Industrial Complex, Reentry 
UNPACKING EMPOWERMENT DISCOURSE WITHIN

A WOMEN'S REENTRY ORGANIZATION

AMANDA N. MILLER

A Thesis Submitted in Partial

Fulfillment of the Requirements

for the Degree of

MASTER OF SCIENCE

Department of Sociology and Anthropology

ILLINOIS STATE UNIVERSITY

2016 
(C) 2016 Amanda N. Miller 


\section{UNPACKING EMPOWERMENT DISCOURSE WITHIN}

A WOMEN'S REENTRY ORGANIZATION

AMANDA N. MILLER

COMMITTEE MEMBERS:

Livia Stone, Chair

Gina Hunter 


\section{ACKNOWLEDGMENTS}

Immeasurable appreciation and deepest gratitude to my committee chair,

Dr. Liv Stone, for her incredible amounts of patience and support throughout this process. The only reason I finished this on time was because of your strength as an advisor. Know that I am absolutely honored to be your first graduate student and I hope I made you proud.

I would also like to thank Dr. Gina Hunter for her willingness to be on my committee and for all of the work that goes into that commitment. You are one of the kindest and most caring individuals that I have had the pleasure of knowing.

A special thank you to my family for their unconditional love and support throughout. Your weekly check-ins, words of encouragement, and patience with my stressed-out person did not go unnoticed.

To M.J.W. for your wit, intelligence, passion, beauty, and incredible love for me. Thank you for being my person.

To my cat for being the best companion a queer could ask for.

And finally, I would like to thank my cohort, students, and faculty of the anthropology department. You are wonderful and I wish you all success and happiness.

A. N. M. 


\section{CONTENTS}

Page

ACKNOWLEDGMENTS $\quad$ i

$\begin{array}{ll}\text { CONTENTS } & \text { ii }\end{array}$

\section{CHAPTERS}

I. THE PROBLEM WITH EMPOWERMENT IN COMMUNITY SOCIAL SERVICES 1

Statement of the Problem 1

Research Questions $\quad 7$

$\begin{array}{ll}\text { Methods } & 7\end{array}$

$\begin{array}{ll}\text { Chapter Organization } & 8\end{array}$

II. REVIEW OF THE LITERATURE 10

Incarceration, Women Offenders, and Reentry 10

Empowerment Approaches Within Social Work Organizations 18

Anthropological Approaches to Gender and Prison 22

III. UNPACKING EMPOWERMENT 26

$\begin{array}{ll}\text { Introduction } & 26\end{array}$

Piper: A Women Offender Post-Release 28

Shay: Case-Manager and Proponent of the Empowerment Approach 38

Unpacking Empowerment 39

IV. EMPOWERMENT AS GOVERNMENTALITY 48

Introduction $\quad 48$

Unpacking Professionalism 48

V. SUMMARY, CONCLUSIONS, AND

ALTERNATIVES $\quad 62$

$\begin{array}{ll}\text { Summary and Findings } & 62\end{array}$ 
Alternatives?

REFERENCES 


\section{CHAPTER I}

\section{THE PROBLEM WITH EMPOWERMENT IN COMMUNITY SOCIAL SERVICES Statement of the Problem}

Piper is a middle-aged, white, college-educated, former female offender from Illinois. Piper was first incarcerated for theft when she was a young adult. She did not see the inside of a cell again for another ten years. In between prison sentences, she was employed and supporting two children. She was also diagnosed with stage four melanoma, and undergoing chemotherapy. As her health declined, she eventually found could no longer work. In order to provide for her family, she began shoplifting and selling the merchandise. With her cancer diagnosis, she could get prescriptions easily from her doctor and started forging prescriptions to increase the dosage or amount of pills so she could sell the additional ones for a profit. Both led her to her second incarceration in the Illinois prison system.

After being released from prison, Piper received services from an organization I will call Jareth for about one year. Jareth is a social service agency in a small town in Illinois that helps recently incarcerated women transition from prison to the community. Helping women to find employment, safe housing, and other needed services, they hope to help women become independent and successful, while working to lower the recidivism rate. This organization specifically works through a framework of empowerment in their aim to help women in the community. 
Piper was considered a successful Jareth client when I met with her. As a middleaged, white woman with a degree in psychology, she was not representative of the average female inmate, or Jareth client - she is relatively privileged. Her experiences leaving prison were also unlike many other women: she was released with a place to live, a supportive family, and a source of income through Social Security Disability Insurance. Even with the added support from her family, she still relied on Jareth to help her get back on her feet by attending therapeutic groups and case management. She describes Jareth as an incredibly helpful organization but she admits that even with all of their help she still could not find employment with her criminal record. She explained that she would get really frustrated when staff continued to push her to fill out applications even though she was repeatedly turned down for jobs-even those for which she had proper qualifications. Still unemployed when we spoke, Piper lived in an apartment with her daughter and survived off her monthly disability check.

I interviewed Shay, the primary case manager with Jareth, after speaking with Piper. Piper's story stuck with me as Shay described her role with the organization and the programs that they offer to try to help women succeed. She told me that what Jareth does is, "all from an empowerment standpoint and we are trying to empower women and educate our community". I was immediately intrigued by the contradictions between Piper's story and Shay's vision of what Jareth does. While Jareth frames previously incarcerated women as disempowered, Piper, and other convicted women are perhaps better understood as women who have wielded very specific (and unacceptable) forms of power. Attention to the gendered dimensions of criminalization shows that women convicts have often resisted gendered ideas of appropriate femininity through 
committing crimes. Jareth's empowerment discourse constructs these women as disempowered in order to then teach women how to employ a more appropriate form of power by encouraging these women to be professional, and to then use their energy to find employment. Piper was considered a successful Jareth client. But, Piper was only "succeeding" due to the disability check she received from her cancer diagnosis. Like all of Jareth's clients, Piper shared the difficulty of finding a job despite having a criminal record.

Empowerment is a complex term and is understood and used in numerous ways whether it be within social work, social movements, development, and/or feminism. One such definition, from social work, is "the process of increasing personal, interpersonal, or political power so that individuals can take action to improve their life situations" (Gutierrez 1990, 149). From this perspective how should empowerment help Piper or any other client of Jareth? What does empowerment ask of criminalized women? Why does Shay find the framework of empowerment useful? To answer these questions, I turn to critical and Foucauldian perspectives on power and subjectivity.

From critical and Foucauldian perspectives, "empowerment" is not a neutral goal, but one that works to internalize state power. In this thesis, I consider Michel Foucault's ideas of power and subjectivity with a focus on governmentality. Subjectivity seeks to understand how "certain bodies, certain gestures, certain discourses, certain desires come to be constituted as individuals" (Foucault 1980, 98). Foucault (1980) shows the different modes by which human beings are made subjects, focusing on three primary modes of subjectification including: (1) modes through knowledge (2) practices which divide the subject according to normative binaries, and (3) practices of 
self-governmentality. My research primarily focuses on the third mode of subjectification: self-governmentality. Governmentality, for Foucault $(2007,108)$, is an assemblage of "institutions, procedures, calculations, and tactics that capacitate a form of power that has the population as its target, political economy as its major form of knowledge, and apparatuses of security as its essential technical instrument".

Michel Foucault (1977) argued in Discipline and Punish: the Birth of the Prison that prisons aim to control and normalize desired behaviors. Scholars of the prison industrial complex have explored this new rationale, arguing that prisons are no longer focused on correction and reintegration but on assessing and managing risks. Through the confinement of people who are classified as risky, prisons use various archictectural, physical, and emotional disciplinary mechanisms to normalize certain desired behaviors and remove the potential for later threats.

The neoliberal transformation of the state since the 1970s resulted in an increase in penal institutions that focused on the regulation of marginalized populations rather than in response to an increase in crime. Katherine Beckett and Bruce Western (2001) argue that the rapid growth of the U.S. prison population over the last two decades of the twentieth century coincides with a decline of the welfare state. Further, while shifts in crime rates, economic, and political changes most commonly justify incarceration, the authors argue that the rise in the incarceration level is due to "welfare state retrenchment." This means that as welfare services have been reformed, cut, and dismantled, populations dependent on these services become more vulnerable and thus a greater target of the criminal justice system. 
Despite Foucault's history of the prison (1977) and larger literature that engages gender, the prison industrial complex, reentry, and, subjectivity is rarely considered. Accordingly, Dean Spade argues for a model of thinking about power and law through an analysis of systems that, "administer life chances through purportedly neutral criteria, understanding that those systems are often located where racist, sexist, homophobic, ableist, xenophobic, and transphobic outcomes are produced" $(2011,10)$. In other words, a more complex framework that analyzes subjectivity and the prison industrial complex is necessary. My research considers the complexities of gender in the prison industrial complex through a focus on women's experiences.

Through ethnographic interviews with members of one small organization that helps women transition from prison to the community, this thesis explores and unpacks discourses of empowerment at work in the organizations. I argue that Jareth's empowerment discourse works on a personal and pragmatic level, but is weak against the structural arrangements that disfranchise women offenders. Empowerment does not critique businesses that do not want to employ former prisoners. It does not help the general public understand that prisons do not meet all of women's needs. I show that Jareth's empowerment discourse defines power and dependence in particular ways through appropriate and inappropriate forms of power and dependence. Further, this "empowerment" discourse casts women as powerless victims, language that would be better aimed at the larger community than to the women themselves. Also, empowerment and practices of subjectification are linked together. Jareth's empowerment discourse reflects an important shift in the reconfiguration of governmental methods that give 
women a specific power, namely, professionalism, which is expected to be used through self-regulation within the market

I argue that strategies of empowerment actually serve to meet political goals of neoliberal governmentality. Discourses of empowerment that encourage professionalism are a calculated self-relationship where one must constantly demonstrate that one is able to provide for oneself without the state-aid. Empowerment through professionalism is really then just a new kind of technology of governance as a way for women to gain selfesteem, self-sufficiency, and responsibility -that is, self-regulation - while pushing women towards traditional paths such as employment, even though jobs often remain inaccessible. This benefits the system in place but does not offer women any means of alternative uses of power.

Most incarcerated women will eventually be released from prison and are met with many environmental, social, and personal barriers that impede the chance for successful reentry. With the dismantling of state and federal social services that would have served to help women transition back into society, grassroots community organizations are being created to meet the increasing numbers of men and women as they are released from prison. Organizations like Jareth attempt important work; my critical perspective is not meant to discount such efforts but to demonstrate the insidious forms of neoliberal power. 


\section{Research Questions}

Considering the oppressive, disciplinary nature of the prison industrial complex and the disfranchising society into which women are released, why choose empowerment as a therapeutic mechanism to help women be successful outside of prison? If empowerment is a strategy that assumes a disempowered subject, how does a community organization's attempt to "give" women power produce independence and not dependency? If women are being targeted for strategies of empowerment, is empowerment inherently gendered? Finally, because empowerment as a strategy is held in such high regard within social activism, does its use permit the possibility of finding alternative means of helping women?

\section{Methods}

In order to answer these questions, I conducted ethnographic research over a five-month period in 2015 with a small organization within Illinois, Jareth, which helps women transition from prison to the community. Little to no research had been done up with the organization and they were happy to allow me access to their staff and clients. I was given permission to interview any of the women that were not on parole or probation (per the IRB) as well as any of the male and female staff. I was not permitted to see a list of their clients due to the organization's confidentiality policies but the primary case manager assisted me in recruiting all potential informants. The organization does not have a very large client base and even fewer number of clients that met all minimum requirements to participate. By the end of the research I was able to sit down and interview one former inmate at the organization's headquarters, a male staff member that had interned with the organization, and the primary case manager. 


\section{Chapter Organization}

This thesis is comprised of five chapters. Beyond chapter one, the introduction, is a thorough literature review that engages scholarship on the prison industrial complex and more specifically female offenders within the fields of criminal justice, sociology, critical prison studies, and anthropology. Additionally, the literature review contains scholarship that engages empowerment within the fields of feminism, psychology, and modern development.

Chapter three focuses on unpacking empowerment within the organization in order to better understand questions about the community organization's attempt to give women power as well as their particular notions of independence versus dependency I question whether empowerment is inherently gendered, showing that "empowerment" is predicated on acceptable femininity. Utilizing interviews with Shay, the organization's primary case manager, and Piper, a former inmate, I unpack and demonstrate how incredibly complex empowerment can be within the prison industrial complex and more specifically, within this organization. This chapter argues that Jareth's empowerment discourse works in a narrow frame to help women transition to employment but it does not meet the broader needs of women offenders. The general public does not want to employ former prisoners believe that prison can meet all of women offender's needs. I show that empowerment defines power and dependence in particular ways - through appropriate and inappropriate forms of power and dependence and consider whether Jareth's "empowerment" discourse casts women as powerless victims. More political 
and critical aspects of empowerment, such as community education, are also part of Jareth's goals but frequently take a second place to direct work with clients.

Chapter Four is concerned with how logics of empowerment and practices of subjectification are linked together. This chapter engages the question: Considering the oppressive, disciplinary nature of the prison industrial complex in which incarcerated women are being released, why choose empowerment as a therapeutic mechanism to help women be successful outside of prison? I argue that Jareth's empowerment discourse reflects an important shift in the reconfiguration of governmental methods that gives women the specific power of professionalism, which is expected to be used through selfregulation within the job market. This strategy of empowerment meet political goals of neoliberal governance and foster a calculated self-relationship where one must constantly demonstrate that the ability survive without state aid. I argue that empowerment through professionalism is a new technology of governance. Women may gain self-esteem, selfsufficiency, and responsibility - self-regulation - but are also pushed towards traditional paths such as employment. This benefits the system in place but does not offer any means of alternative uses of power.

Chapter Five, the conclusion, summarizes the arguments above but also considers why empowerment as a strategy is held in such high regard within social activism. I argue that such reliance on empowerment limits the possibility of finding alternative means of helping women While offering alternatives is beyond the scope of this research, I do consider the possibility of thinking about prisons as sites of disability. 


\section{CHAPTER II}

\section{REVIEW OF THE LITERATURE}

\section{Incarceration, Women Offenders, and Reentry}

Meda Chesney-Lind states two important tenets of feminist criminology:

First, women's and girls' crime was virtually overlooked, and female victimization was ignored, minimized, or trivialized. Second, whereas historical theorizing in criminology was based on male delinquency and crime, these theories gave little awareness to the importance of gender - the network of behaviors and identities associated with the terms of masculinity and femininitythat is socially constructed from relations of dominance, power, and inequality between men and women. $(2013,3)$

When ethnographically analyzing larger questions of reentry, power, gender, and subjectivity, it is important to recognize that there is already an unequal power dynamic in place between men and women that plays a role in how women in the criminal justice system are understood and researched. Part of this inequality is that the criminological literature is male-centered and therefore requires a perspective that engages how women's crime is overlooked, minimalized, and compared to men as part of a larger literature review that would not be present in research completed on men's prisons and reentry. Further, gender is but one axis of inequality but this must also be considered in conjunction with race and class status.

Joanne Belknap (2001) writes from a feminist criminology perspective, which is interested in how gender intersects with crime and the criminal justice system. Belknap 
utilizes a feminist criminological perspective to make women's experiences more visible within the criminal justice literature. Historically, women offenders were often left out of the scholarly literature and when they were included, researchers tried to understand women's offending through their prior research on male offending. Believing women's crime to stem out of biological factors and men's crime out of socioeconomic factors, women were studied through a sexist lens. Belknap uses her position within feminist criminology to critique the maleness of literature and the inequalities women face through trying to centralize women's experiences.

Angela Davis (2003) specifically addresses the gendered structures of society in her history of women's prisons and gendered prison issues. She argues that there is a tendency to compare men's prisons to women's prisons, assuming that men's prisons are the norm and then analyzing what is different for women based on this. Davis encourages an analysis of the prison system through a lens that considers the prison a gendered structure and that within both men's and women's prisons are gendered practices.

Davis (2003) notes that male criminality has always been seen as more "normal" than feminine criminality and those women who are punished are seen as more threatening to society than criminalized males. According to dominant discourse, women convicts are failed women and seen as having transgressed fundamental principles of morality and womanhood. Davis argues that it is important to understand that as prison became major form of punishment, women were continually subjected to other forms of punishment such as psychiatric institutions. She further argues that psychiatric institutions have served a similar purpose for women that jails and prisons have served 
for men. Criminal men, therefore, are constructed as deviant while criminal females are constructed as mentally ill. Gendered as female, this kind of mental illness is also highly sexualized. Also important to consider is that black women experienced punishment differently through the context of slavery than white women. Davis $(2003,68)$ writes:

The notion that female 'deviance' always has a sexual dimension persists in the contemporary era, and this intersection of criminality and sexuality continues to be racialized...thus, white women labeled as 'criminals' are more closely associated with blackness than their 'normal' counter-parts.

If class and race are considered, white affluent women are generally considered mentally ill if they break the law, while black and poor women are considered criminals.

Beth E. Richie (2012) considers how white supremacy, class, and gender intersect within the United States in what she classifies as a "prison nation". Richie $(2012,3)$ explains:

A prison nation refers to those dimensions of civil society that use the power of law, public policy, and institutional practices in strategic ways to advance hegemonic values and to overpower efforts by individuals and groups that challenge the status quo a prison nation depends on the ability of leaders to create fear (of terrorism or health-care reform); to identify scapegoats (like immigrants or feminists); and to reclassify people as enemies of a stable society (such as prisoners, activists, hip-hop artists).

Within the prison nation, violence towards black women increases and this stems from state policies that limit access to social services. Prison nations depend on the creation of laws with strict enforcement by the state that target and punish people who violate these norms. Richie (2012) demonstrates that within the United States are hegemonic ideas about appropriate gender roles and presentations that intersect directly with race, crime, and punishment. Because the United States values white standards of beauty, virginity/purity, and passive weak women - women of color are seen as less feminine 
because of their presumed hypersexuality, aggressiveness, poverty, and physical difference. This does not fit into a normalized idea of womanhood and leaves women of color open to punishment. Through qualitative interviews with black women in communities across the United States, she stresses the need for attention paid to black “social marginalization and community disempowerment" (12).

Understanding the diversity of experience and consequences of criminalization is particularly important given mass incarceration in the U.S. Young and Reviere (2006) show that the United States incarcerates more women than any other country in the Global North and argue that current criminal justice policies and programs are overly punitive in nature. Interestingly, Belknap (2001) considers a contradiction in this trend: the increase in women's incarceration has not been accompanied by an increase in women's crime. Women are committing less violent crimes, and there is an increase in the construction of women's prisons. Belknap argues that the increase in women's incarceration is due to policy changes that stem from a punitive focus on drug-related crimes, the primary set of laws these women are breaking.

Meda Chesney-Lind (2002) also considers how mass incarceration affects women specifically. Arguing that the "growth of women's incarceration is a reflection of public policy decisions that have ignored women's needs and behaviors" (79), ChesneyLind $(2002,80)$ considers the question "How do you handle women in a world built to house presumably violent men?" Historically, she argues, there was no correctional system in place for women and when incarceration rates began to rise, the lack of system became a problem that could no longer be ignored. The current system places women in facilities designed for violent, male offenders and treats women as if they experience the 
same kinds of problems inside and outside of prison under the guise of "fairness". When men's crimes and needs are presumed to be the same as women's, prisons for women are not designed to fit their circumstances. They do not accommodate the women's population that tends to have more instances of mental and substance abuse problems as well as reproductive health care needs. It is unnecessary to create large supermax facilities for women staffed with primarily male correctional officers, and lacking in treatment-based interventions. The consequences of this system are sexual assault and abuse scandals, and lack of adequate health care.

According to the Bureau of Justice Statistics $(2015,1) 59 \%$ of women were in federal prisons for drug offenses while only $50 \%$ of men were in federal prisons for drug offenses. Within state prisons, $24 \%$ of women were convicted of drug offenses compared to $15 \%$ of men convicted for drug offenses (Carson, 2015, 1). Because women are more likely to be convicted of drug-related crimes, harsh sentencing laws for drug offenses and parole regulations about drug use disproportionately impact women.

Belknap $(2001,163)$ states that the system in place for women offenders comes down to "institutional sexism" within prisons. There are significantly fewer women's prisons than men's prisons in the United States, which increases the distance that friends and family must travel to visit inmates and increases the psychological distress women experience from lack of contact with their support network. There are a lack of educational and vocational opportunities available to inmates within prisons, but this is much more of a problem in women's prisons. Sexism is evident in how criminal justice officials justify the decreased vocational and educational opportunities to simply a numbers game where because less women are incarcerated there does not need to be the 
same opportunities available to women as there are to male offenders. This same thinking also applies to mental health and substance abuse treatment options - fewer women equals fewer opportunities. This is further evident in the inhumane treatment of women including vaginal searches that occur after court appearances, after hospital visits, even on pregnant women. Body cavity searches are invasive, frequently performed by correctional officers rather than medical staff, and can be dangerous due to bleeding and possibility of infection. Further, Belknap (2001) explains how incarcerated women experience a lack of reproductive freedom including forced abortions, lack of proper equipment for consensual abortions, and compulsion to put their children up for adoption.

Ann Jacobs (2001) describes female offenders as women with a multiplicity of problems. She writes,

They are overwhelmingly poor and substance abusers. They are also victims of abuse and violence. Many are depressed and suffer from various forms of mental illness. They experience a high rate of HIV infection, other sexually transmitted diseases, tuberculosis, and untreated chronic disease. A high percentage are homeless or marginally housed. Typically, they are under educated, unemployed, and have minimal legitimate work histories. On average, $75-80$ percent of them are mothers. $(2001,44)$

While men struggle with similar issues such as poverty, substance abuse, previous victimization, mental and physical illness, homelessness, and unemployment, these present differently in women. For example, women have disproportionate histories of victimization often times at the hands of family or significant others which potentially leads to substance abuse. Additionally, women have a harder time finding housing as there are fewer shelters that house women. Women are often their children's primary caretakers and most shelters do not house families. Women also have less work experience and having a felony limits typical employment opportunities for women. 
Barbara Owen (2003, 245) states,

The problems that lead women to prison - abuse and battering, economic disadvantage, substance abuse, unsupported parenting responsibilitieshave become more criminalized as contemporary society ignores the context of these women's lives. Because many of these individuals are poor, are from minority communities, and behave in ways outside middleclass sensibilities, prison has become the uniform response to problems created by inequality and gender discrimination.

Further, when these women leave prison, communities are unable or unwilling to deal with the complexity of problems that criminal justice policies, prisons, and society create. Young and Reviere $(2006,179)$ write, "Women, particularly women of color, are crowded into facilities designed for and by men — before they are returned, with old problems intact, and probably new ones, to a community ill-equipped to ease the transition.”

Hattery and Smith (2010) argue that the reentry process is also both gendered and racialized. Because children are more likely to live with their mothers than their fathers, women have an added problem of maintaining contact with children once in prison. Their children are usually placed in the foster care system while their mothers are in prison, and mothers face great barriers in re-gaining contact with children once they are released. Hattery and Smith (2010) stress that the problems women face during reentry were exacerbated by the race and welfare reforms of 1996 that prohibit people with felony drug convictions from important services such as public housing and Temporary Assistance for Needy Families (TANF). This legislation makes it even more difficult for women to regain custody and provide for their children. 
Beth E. Richie (2012) considers how white supremacy, class, and gender intersect within the United States in what she classifies as a "prison nation". Richie $(2012,3)$ explains:

A prison nation refers to those dimensions of civil society that use the power of law, public policy, and institutional practices in strategic ways to advance hegemonic values and to overpower efforts by individuals and groups that challenge the status quo a prison nation depends on the ability of leaders to create fear (of terrorism or health-care reform); to identify scapegoats (like immigrants or feminists); and to reclassify people as enemies of a stable society (such as prisoners, activists, hip-hop artists).

Within the prison nation, violence towards black women increases and this stems from state policies that limit access to social services. Prison nations depend on the creation of laws with strict enforcement by the state that target and punish people who violate these norms. Richie (2012) demonstrates that within the United States are hegemonic ideas about appropriate gender roles and presentations that intersect directly with race, crime, and punishment. Because the United States values white standards of beauty, virginity/purity, and passive weak women - women of color are seen as less feminine because of their presumed hypersexuality, aggressiveness, poverty, and physical difference. This does not fit into a normalized idea of womanhood and leaves women of color open to punishment. Through qualitative interviews with black women in communities across the United States, she stresses the need for attention paid to black "social marginalization and community disempowerment" (12).

Understanding the academic scholarship that specifically addresses women in the criminal justice system is important for this research because it addresses how women are often invisible both in the criminal justice and reentry literature but also in policy which 
marginalizes women's needs and ignores how women enter the criminal justice system differently than men.

\section{Empowerment Approaches within Social Work Organizations}

Scholars Rapp, Shera and Kisthardt (1993, 733) write, “Empowerment as

a philosophy and as a set of related strategies represent a concept that few social workers, researchers, program managers, and practitioners hesitate to embrace.” Empowerment approaches within social work have been utilized in many places within the United States including but not limited to community-based organizations, public welfare offices, within social movements, private and not-for-profit organizations, among many others (Simon 1994). Gutierrez (1990, 149) defines empowerment as, "the process of increasing personal, interpersonal, or political power so that individuals can take action to improve their life situations." Within social work agencies, empowerment approaches consider the client's strengths in order to improve self-esteem, power and sense of community (Simon 1994). Furthermore, "empowerment based social work has sought to exploit the pockets of robustness in clients' personalities and the resourcefulness and resilience that may be found in their families, friendships, neighborhoods, and subcultures" (Simon 1994, 1-2). Empowerment, put more simply, aims to achieve self-efficacy or to lessen the belief in individual powerlessness (Conger and Kanundo 1988).

Cassandra Bransford (2011) explains that social work in the United States utilizes two competing models when working with clients. The first is a paternalistic approach where the social worker often defines what is in the best interest of the client, 
which creates an obvious power imbalance within the client-social worker relationship (Bransford 2011). The second, which at times overlaps with the paternalistic model, is the empowerment approach, which considers the client as the "expert" in their own treatment and the social worker provides support and guidance (Bransford 2011). Empowerment approaches within social work agencies try to avoid the use of paternalism when working in a client-social worker relationship (Simon 1994). Within this strategy is the notion that disempowered individuals and/or communities seek "freedom, justice, and fulfillment" $(1994,3)$. Rather than empowering a client to reach their own professional level or telling clients what is in their best interest, Simon encourages empowerment to be used as a collaboration where professional guidance helps the client find success, whatever that might be, for themselves. Importantly, "Empowerment based social work, by contrast, has highlighted the importance of reinforcing and expanding clients' extant capabilities and resources while attempting to help people heal their traumatized bodies, minds, spirits, and neighborhoods" (Simon 1994, 14).

Gutierrez, Parsons, and Cox (1998) identify the principles of empowerment within social work. First, the scholars stress that the agreed-upon setting between social worker and client needs to be both safe and supportive in order to be productive. Second, considering the cultural, personal, and political context of the client's collective and individual situation is very important as "structural inequalities and oppression play major roles in powerlessness" $(1998,221)$. Third, empowerment should be a collaborative process that promotes self-confidence and self-respect that provides for the client the opportunity to gain awareness of their own problems and see themselves go from "passive to active consumers of services" (221-222). Finally, the social worker must 
take on a multiplicity of roles whether it be as an advocate, teacher, adviser, and then teach many kinds of skills like managing money, getting employed, applying to schools, to the client.

According to Gutierrez, Glenmaye, and DeLois $(1995,249)$ part of empowerment is to address how powerlessness has a role in "creating and perpetuating personal and social problems.” Barbara Soloman (1976), speaking specifically about black communities, argues that the relationship between "power, powerlessness, and the processes of human growth and development" is important; defining powerlessness as "the inability to manage emotions, skills knowledge, and/or material resources in a way that effective performance of valued social roles will lead to personal gratification" $(1976,16)$.

Glenmaye (1998) engages empowerment as a kind of transformation from powerlessness towards powerfulness whether it be through personal and/or political power. Speaking specifically about women's empowerment, she puts forward that women both individually and collectively face powerlessness and that a goal of social work is to empower women. "In talking about women as a group, one must see woman as comprised of a complex set of interlocking individual and group experiences including at least race, class, and gender" (Glenmaye 1998, 29).

The preceding discussion shows two very different approaches to understanding women's prison and reentry struggles. The criminological literature emphasizes both how sociocultural and economic factors play a large role in dictating who is seen as a criminal, what is considered criminalized, and what barriers exist that 
make it more likely for a person to enter the criminal justice system. The empowerment literature emphasizes personal agency, individual powerfulness and powerlessness, and responsibility. This raises an interesting tension. First, gender inequality is very much a real consequence of a patriarchal culture. Empowerment approaches assume that women feel individual powerlessness as a belief rather than a systemic issue and push for selfefficacy and responsibility and there is a tension in how self-esteem, power and sense of community as agentive forces overcome the larger power structure of the state and the prison industrial complex. There are factors such as having a criminal record that limit the employment opportunities for men and women as they leave prisons that no amount of self-esteem could overcome. There is a presumption that the individual is responsible for resolving larger issues that plague the criminal justice system and larger culture such as poverty, education, and racism.

These arguments about powerlessness are particularly relevant to my larger arguments about empowerment in that they speak to the existence, whether agentive or structural, of powerlessness and that this has a large impact in how women navigate the reentry process. The agentive empowerment as understood within social work does not adequately address the structural powerlessness that exists within the criminal justice system and the United States. For example, how does feeling powerful become a solution for impoverishment, unemployment, gender inequality? How does individual empowerment remove the barriers in place that limit felons from achievement within their communities? 


\section{Anthropological Approaches to Gender and Prison}

Anthropological literature that engages the criminal justice system, while very limited, has endeavored to engage men and women's criminality and experiences in the criminal justice system and in their everyday lives. The literature as a whole, while not directly related to women's reentry and empowerment, is useful in that it provides a holistic lens that often requires a thorough engagement with cultural tensions between structure and agency.

Barbara Owen (1998) conducted ethnographic research in the world's largest female prison, Central California Women's Facility (CCWF). Owen (1998) finds that incarcerated women experience prison differently than men, and argues that prison is gendered and women navigate prison life based on their experiences of patriarchy, limiting economic opportunities, discrimination, and the stigma of having a criminal status prior to incarceration. Owen states, “female offenders' second-class status as women shaped their lives before prison, whereas patriarchal privileges extend to all classes, ethnicities, and races of men, regardless of their economic marginality" (1998, 40). This means that women come from a place of powerlessness; the way they understand their opportunities in life and how they relate to other women is directly impacted by patriarchy. Gender inequality and powerlessness is evident in how women manage their incarceration. For example, rather than the violence commonly utilized by males to gain or maintain power in prison, Owen indicates that women seek out networks of social support and thrive on feelings of belonging that help them to cope with the distresses of incarceration and to ensure survival. 
Lori Labotka's (2015) dissertation addresses gender and criminality as it intersects with punishment and the body in a prison in Arizona. She argues that incarceration is a challenge to women's personal identities through the regulation, control, and construction of inmates as individuals. Expanding on literature that defines prison intake procedures as rituals of humiliation that rebuild the body in the image of the institution, Labotka (2015) explores the ways humiliation in prison manipulates normalcy that distances prisoners from their desired identities. She considers these practices as challenges to a prisoner's sense of humanity and ultimately considers punishment as a ritual of humiliation. Exploring the linguistic and semiotic mechanisms through which the state manipulates the confined female body through humiliation, she argues that through state manipulation and discipline, the cultural body is denied by the prison.

James B Waldram's (2012) ethnography explores a specialized Canadian unit within a prison, the Hound Pound, which provides treatment for offenders that have committed sexual offenses. Waldram (2012) considers the relationships between punishment and treatment as well as discourse and narrative within therapeutic interventions. A larger argument that this research makes is that the therapeutic interventions being used to manage and treat sexual offenders contain inconsistencies that show how punishment and treatment both intersect but also contradict. This means that through analyzing how we treat those some would consider mentally ill and others as predatory individuals who should be locked up - cultural notions of treatment and punishment are illuminated. This same kind of tension arises in my research that thinks about how empowerment as a mode of agentive treatment to deal with poverty, 
unemployment, and lack of available resources intersects with structural barriers and cultural understandings of punishment and criminalization.

K. Drybreads' (2014) research is an example of anthropological research within a juvenile prison, the Center for Adolescent Social Adjustment (CASA), in Brazil. Her work explores masculinity, performance, and childhood through the construction of the sujeito-homem (753) or "man-subject" in order to better understand how masculinity and children's development and performance of proving oneself intersects with the legal definition of adulthood. Her work is important to my research because it is another example of anthropology that explores incarceration but also because it theoretically engages power dynamics, class, race, and gender. In addition, it takes into consideration the cultural backgrounds of the informants, the larger cultural understandings of crime, childhood, and masculinity. Understanding how masculinity is thought about culturally in this context helps to set up the tensions that exist between the legal system and definitions of adulthood. Understanding how gender plays a role within the legal system as a cultural and defining factor is useful in my research. How the United States normatively understands femininity and how these understandings are in tension with how the U.S. often conflates criminalization with masculinity definitely factors into how we treat women as offenders within the system but also during the reentry process.

Susan Koski and S.E. Costanza “investigate female offenders' narratives about reentry and examine their responses to gender-reentry programming... our interviews cast in sharp relief the necessity for gender-specific theory to explain crime" $(2015,71)$. Their findings show that women offenders' needs are different from those of male offenders, often because of women's history of victimization and drug abuse, and 
thus a gender-specific reentry program is necessary for successful reentry. Stating, "In much of the interview content, we observed that much of their criminal behavior emerges from their own understanding of gender-specific roles" (84). What the authors mean by this is that gender plays a role in how and why women commit crime. Gender factors into increased victimization and drug abuse that plays into which crimes women commonly commit.

This particular research is crucial to my research as it begins a qualitative discussion about the problems for successful reentry that Jareth, a gender-specific organization, also believes in, but the authors do not consider how focusing on gender, similarly to focusing on empowerment, deals with the structural barriers that the criminological literature cites. My research takes this a step further and engages empowerment as a modality of treatment within a gender-specific agency that focuses on the needs of offenders post-release, but considers the structural and agentive tensions at play that limit the effectiveness of empowerment as a sole intervention. 


\section{CHAPTER III \\ UNPACKING EMPOWERMENT \\ Introduction}

This chapter examines the logic of empowerment. In order to understand why empowerment seems like a logical approach, I will focus this chapter on unpacking the complexities of empowerment within the prison industrial complex. I argue that Jareth's empowerment discourse works on a personal and pragmatic level, but is weak against the structural arrangements that disfranchise women offenders. Empowerment does not critique businesses that do not want to employ former prisoners. It does not help the general public understand that prisons do not meet all of women's needs. I also argue that Jareth's empowerment discourse defines power and dependence in particular ways through appropriate and inappropriate forms of power and dependence. Further, this "empowerment" discourse casts women as powerless victims, language that seems more aimed at the larger community than to the women themselves. Also, empowerment and practices of subjectification are linked together and thus Jareth's empowerment discourse reflects an important shift in the reconfiguration of governmental methods that gives women a specific power, professionalism, which is expected to be used through selfregulation within the market.

Jareth assists women in securing a variety of potential needs. Jareth's mission is to, “...provide long term supportive services to women who have been incarcerated or are on probation". The goals of the organization include, "to collaborate 
with all available local social service agencies to assist the women to remain free of future court involvement." Their vision is, "to significantly reduce recidivism." Through Jareth, women can receive assistance in attaining state identification, transportation, employment preparation, housing, food, and clothing resources, medical and prescription assistance, GED, education, and job training linkages, as well as long-term counseling and case management. Further, Jareth provides services such as family reunification including parenting resources, access to a spiritual community of the participant's choosing, a support system, and special opportunities such as vocational training, art therapy, and holiday gatherings when available.

Jareth began in December 2004 as a task force of two professional women to find solutions to homelessness and related issues such as mental illness and addiction for single women in the county. In 2005 Jareth was incorporated as an organization and by 2007 it became a registered 501c(3) organization. At the same time Jareth began collaborating with the city government to find a house as a headquarters and eventual place of residence for these women. After several years of applying for grants and other forms of funding for additional transitional housing and mission awareness through various organizations in the area, several properties were purchased and renovated. By June of 2014, Jareth held its first vocational training program to help educate women with a felony or misdemeanor. During this same time period, Jareth began providing fulltime case management/counseling services. Most recently in July of 2015, Jareth was awarded funding through the county health department to hire a residential counselor and a job coach. Staff say that they are roughly one month away from allowing women in the community to move in to their transitional housing program. 
Jareth staff is small with only one paid program/case manager, volunteer and intern staff that assist with the running of programs and funding drives such as their annual garage sale, a board of community members that make larger decisions about the state of the organization, and in the near future additional staff to meet the needs of the growing residential and vocational programs.

\section{Piper: A Woman Offender Post-Release}

Interested in talking with me about her life and experiences in prison, a former offender I will call Piper, contacted me by phone and we met at Jareth house. I had only been to the house one other time at this point and staff were supposed to meet me to unlock the door. A middle-aged, white woman with a noticeable pain to each of her steps walked up to me while drinking a large gas station soda and cautiously asked if I was the one she was meeting for an interview. Aware that she was staring at my tattoos, I became very self-conscious and stumbled through an introduction while both shaking her hand and informing her that the primary case manager knew about our meeting and would be letting us inside. Chatting casually about the summer heat, we climbed the porch stairs and rang the doorbell.

From the outside, Jareth looks like an ordinary white, two-story house not unlike the other houses on the street. There are no signs pointing out that this is more than just a residential building. Ringing the doorbell several times with no answer I started to get nervous that nobody was there and I would either have to reschedule or think of a new location quickly. Piper suggested that we go around back and try the other door but it was also locked. Knocking again we were finally able to get someone to answer who 
kindly informed us that the case manager was in a meeting with a client and that we could come in. I had been informed earlier that I could use the second floor as a place to hold my interview so we made our way up the wooden staircase. The second floor was still in the process of being transformed into a housing space for up to three women. A room with two armchairs and a small kitchen seemed like the best space to talk without interruption.

Piper and I began by talking about her childhood and family but she was very guarded. Describing her childhood as "good" and the relationship with her parents as also "good" she finally opened up a bit and told me it continued to be this way until she was a teenager. Describing herself as rebellious at that age, Piper was incarcerated for her first time at age 19. Having told me that her relationship with her family suffered during her time in prison, because they did keep in contact with her but did not visit. When she paroled out of prison, a friend found a place for her to live and she remained there for seventeen years until her second incarceration.

Piper's first incarceration was at Dwight, a prison that is no longer operating in Illinois. Upon its closing she was transferred to Logan Correctional Center in central Illinois where she finished out her sentence. Telling me she did much of her time at Logan, she casually mentioned that it was coed at that time. Intrigued, I ask her to explain how that worked. According to her experience at Logan, women and men had different wings but were together during meals, educational classes, and recreational times. While this is no longer the case in any of the Illinois prisons, Piper described prison as feeling more like a restricted college campus rather than a prison. She had the opportunity to take college classes while incarcerated which allowed her to get an 
associate's degree in data processing and commercial arts which may explain why it felt like a college campus to her but more like a prison to other women.

Getting deeper into the gendered aspects of prison Piper stated, I think society realizes that women, for the most part, are in prison to take care of their family. I pretty much know that there is not that many rapists, murderers, and all that, I mean there are some but not like there is in the men's prison. Men don't go to prison for shoplifting, I mean they do, but not like the women do, or for bad checks, or whatever they have done. I think women are in prison more for either protecting themselves or trying to take care of their family.

Implying that women are not incarcerated for violence, Piper engaged women's criminality in a way that is supported by a large body of criminological literature that argues that women take different pathways to prison than men (Belknap 2001; ChesneyLind 2007; Owen 1998) Piper herself was incarcerated for theft and later for forgery which is cited by the same scholars as common crimes committed by women.

Reentry is also gendered as seen both in the literature and exemplified by Piper. I asked Piper if men and women have a similar reentry experience. Shaking her head no she said:

I would say maybe women have it a little harder, but I'm not a man so I don't know what struggles they have, but a man's girlfriend or wife will stick by them a whole lot easier than any girl's boyfriend or husband would and unless they were a single-father taking care of the child which you know seven out of ten times the woman is always taking care of the kids and separation of the kids from the mom is a little stronger than when they are from a dad, and when you get out you have to get your kids back from where ever they are.

Much literature posits the difficulties women have when they are released from prison (Belknap 2001; Richie 2012; Owen 1998). One of the biggest, as Piper describes, is getting custody of children. The first day Piper walked out of prison she was able to get her daughter back after making it clear with her mother that she was not to keep her 
daughter beyond the day she was released. Piper is really quite fortunate though, as the reality for most women is that they have no social resources that would allow for longterm child care and they lose custody of their children while in prison (Belknap 2001). Even if getting custody of the children is successful, being the primary caretaker of children is stressful on its own and especially so right after release from prison. Piper says she was fortunate enough to have a place to go upon release, but does say it is really quite difficult to juggle getting custody of your children, finding a place to live, searching for employment, and all while meeting additional parole requirements.

Piper explained that there's not a lot of help out there when you walk out of prison and especially so if you don't have social support. She stated, "At least the first time around they gave you the bus ticket if you needed it, if not you had a ride to pick you up, but they handed you at least 50 dollars and before that at least 100, now they give you nothing". Piper explained to me that it wasn't as much of a problem getting a job after her first time in prison stating, "I did work at a couple of different places, and I had a good job working as a secretary for retired seniors at the YWCA". Acknowledging that a lot of people do not get these same chances upon release from prison she stated,

I saw a girl that came in that I knew had been in prison before but thought that I would just let her slide by not bringing it to anybody's attention because I feel people should be given a second chance, but unfortunately she did do something wrong and at that time the YWCA didn't do background checks, then it became mandatory.

Piper later volunteered the information to her supervisor that she, herself had a criminal background, and even with her extensive time with the company and even temporarily holding a supervisory position while the previous employee was on leave, she was eventually let go because of her record. Fortunately, she was hired by a cleaning 
company and worked her way up the ranks for twelve years until she was diagnosed with stage four melanoma and had to resign.

Through the course of her cancer treatment, Piper became addicted to pain

killers.

I was prescribed anything and everything I wanted, I'm not saying that was the doctor's fault, but it just turned into an abuse...I wasn't expected to live and I was made to be comfortable and then when things weren't going as they should of it just got to the point that I could see how my doctor made prescriptions and I changed a couple of prescriptions.

Eventually getting caught forging prescriptions as well as several shoplifting convictions after stealing merchandise, selling it, and using the money to take care of herself and her children, Piper spent additional time in prison.

I think because I was so sick I was shown mercy...I probably should have gotten a lot more time but was only given four years...up to that time I had gone seventeen years without any problems, no arrests, nothing, and I had a lot of good people by me willing to make those character-type references for me or statements to the judge, so I went in and did my year and a half in prison.

Piper was more positive about her first experience in prison, which she indicated was for theft, only really complaining about the conditions at Dwight. She focused much of her narrative on the co-ed environment and her opportunity to take college level classes. Her second incarceration, which was seventeen years after the first, seemed to weigh heavily on her. Piper spoke of so many more negative, traumatic experiences of incarceration while at Decatur. For example, she explained to me the types of correctional officers that she met while in prison.

More times than none you get the guards that got a badge so they think they are superior. We used to joke like I would love to see them out and about somewhere, how nervous they would get around you. You want to 
treat us like we aren't human. You break laws too so don't look at us like We are nothing, like C.O.'s [correctional officers] respect men a lot more than they respect women.

When asked to explain how this is so, Piper says that the way both the male and female C.O.'s pry, are rude, order you around, and walk around female inmates with a superior attitude that these same C.O.'s would not display around men because, "It's a lot more likely the men will knock one of them out." Describing female correctional officers,

Some of the women would be worse than the men, I don't know, they feel like they have power because they don't have power over their own homes. They can't control their kids or their husband at home so they come here to feel like they can control somebody and boss somebody around, you know?

She further described officers that were not as strict and wouldn't care if she hung a picture of her family on the wall but then described other officers that just came in to rip those pictures down because they were against the rules regardless of how they improved the mood of the inmate. Piper admitted that many guards displayed favoritism over certain inmates. "You will see the guys be a lot nicer to your Barbie-doll looking girl inmates versus the ugly ones." Further, "Some abuse their power, both male and female guards in both facilities, you will have a male inmate or male guards trying to have relationships with the female inmates, this was common." This would sometimes result in tension between fellow female inmates where one would become jealous over another's relationship and report the relationship to another correctional officer who would determine if the inmate was a credible enough source to do an investigation. "There was one C.O. that did get fired, I don't know if charges were ever really filed while I was there but he got escorted out of the building for having relations with women inside the prison and outside the prison once they were paroled." There did (and still does) exist a 
grievance program where inmates can file complaints against correctional officers but Piper saw a lot of problems in this system. She said that even though she never needed to file a complaint that she wouldn't feel comfortable doing it anyway because she would be making a complaint that would be read by these correctional officer's fellow coworkers and, "who are they going to believe?"

She further described prison conditions as inhumane, in part because the guards often harassed and assaulted the female inmates but also because of the poor conditions of the facilities and poor physical and mental health care system. Further, she told me it was nearly impossible to survive without some form of outside income because inmates were paid very little for their labor and the expenses for basic products and healthcare were very high. Outside of the one roll a week of toilet paper, monthly menstrual pads, and state underwear - any other necessities were up to the prisoner to be able to afford. Piper's previous health condition allowed her mandatory visits to the doctor without pay, but according to Piper, anyone requiring a visit to the doctor would have to pay five dollars a visit on a monthly stipend of fourteen dollars. She said that it took almost three visits before the doctor would prescribe meds.

Because Piper was diagnosed prior to being incarcerated, Decatur Correctional knew about her stage four cancer. Piper was required by her doctor outside of prison to get routine checks but they, “didn’t want to do my routine checks because they didn't want to pay for it, so unless you were really sick they wouldn't do anything...how would they know if my cancer is spreading if they never did a cat scan on me?" No major health complications did occur while she was imprisoned for the year and 
a half but she did have a potential major problem right before she was released. Piper had a port for her chemo treatment and at some point the port developed a hole.

Right before I was getting ready to get out they flushed it so I would be good for a month until I got home and saw the oncologist...I had a real bad reaction two days before I went home...I was almost paralyzed, couldn't walk, got back to my unit, laid down... when I was getting ready to parole my favorite nurse was like 'you don't want to say nothing' because then they would have kept me in health care until they found out what was wrong.

Piper chose to say nothing about her health at this time so that she could be paroled.

Piper then told me that she feels bad for other inmates who get sick and do not have chronic illnesses. She feels bad for them because then they have to navigate a health system in which they are required to pay five dollars in order to be seen by a doctor at the health care unit. Having familiarity with how prison health care works myself still did not prepare me for listening to a first-hand account of prison care. Piper explained that once the five dollars are paid, the inmate would still need to be seen at least another two times before they would prescribe any medication. That is fifteen dollars just to be seen. Putting that into perspective, without any kind of family contribution, an inmate makes an average of fourteen dollars a month through prison employment. If that inmate gets sick they will have to use the entire month's income to be treated. If they choose treatment then they have no way to pay for any kind of commissary items they may need for the month. While commissary items do include some luxury items like televisions, candy, and other unnecessary commodities, there is also a significant amount of basic hygiene products that prisons do not give to inmates for free. An inmate receives underwear, bra, menstrual pads, and one roll of toilet paper (two rolls the next week and then back to one roll the week after that). If you need more than 
one or two rolls of one-ply toilet paper a week you have to buy it in commissary. If you want to brush your teeth and hair, wash your clothes (this facility required inmates to wash their own clothes), take a shower with soap and shampoo, wear tampons instead of pads, or wear underwear that has not been used by other people at some point, you have to buy it. These items are not cheap either. I asked Piper to give me examples of prices so I could wrap my head around the math and she told me that an average tube of generic toothpaste is over three dollars, and if you want a brand such as Crest or Colgate, then you would pay more for it. If you have no family to send you any money, you cannot survive off of state pay which is the case for many female inmates. Piper stated,

Luckily they [inmates] meet friends there and when friends go home they will leave you their toiletry items... sometimes I see some really nice girls that have money on the books and can see that someone doesn't have anything and will buy them some essentials. They might not get the uxuries of food but they will give them the essentials of deodorant and things like that.

Now that she is out of prison, Piper is still managing her cancer, but did

receive long-lasting side effects from treatment and is currently living off of disability.

I don't work at this time even though I have tried. When there's a job I know I can do I have tried [to apply] yet I just keep getting turned away because of my record. It doesn't matter that I have a lot of college education, it just doesn't matter. I have tried several places and gotten all of the way to the end of most, but you get the door slammed in your face enough, you don't even know. It gets to the point where I don't care, you get tired of the rejections. It's here [at Jareth] they say keep trying, just keep trying, but you can only try so much, you know, I just can't go accept any job. I can't stand on my feet for eight hours. I could probably do four, but there has been a few sit down jobs and places I have really wanted to go to and applied. For example, at the Salvation Army I applied to be a night auditor... I don't know if was because at that time I was still on parole or what but he's [interviewer] just like 'it doesn't matter how qualified you are, you have a record' and its right there where the door gets shut in your face. 
While Piper's experiences with the prison industrial complex and later with the community cannot be generalized to all female inmates it does speak to issues such as the poor health care in prisons, the assault and harassment by correctional officers towards inmates, the outrageous commissary prices and lack of giving women basic hygiene products, and the difficulty finding steady employment that women do face both inside and outside of prison. As seen by her description of correctional officers, the prison health care system, inhumane treatment of inmates, and the extraordinary difficulties women must face once released from prison it is obvious that there are issues within our prisons and larger criminal justice system surrounding the treatment, confinement, discipline, and perception of inmates.

I was convinced by the end of my interview with Piper that significant reform of the prison industrial complex was absolutely necessary and that the treatment of inmates was inhumane. Further, I really struggled with how punishment was being extended beyond incarceration. It is already difficult emotionally, mentally, and physically to be incarcerated, and then it is an up-hill battle of having to prove to yourself, family, friends, and potential employers that you have been rehabilitated. Included in this battle are significant systemic barriers such as the requirement to disclose your criminal record to your employer that make community reentry almost impossible.

I listened to Piper's experiences of prison, her life, and the community prior to having a semi-formal interview with the primary case manager of Jareth, Shay. Shay worked with recently incarcerated women daily and had a nuanced understanding of these women's lives, struggles, and experiences with the criminal justice system. My discussion with Shay demonstrated that many of Piper's experiences were experiences 
that a lot of these women faced or were facing. Shay told me that Jareth was an organization that wanted to help women succeed in not returning to prison and finding stability through a steady income and safe housing. And yet when I asked her how they were planning on doing this and she told me that it's all from an empowerment standpoint, I was confused. How was empowerment going to help these women? What did empowerment mean in this context?

\section{Shay: Case-Manager and Proponent of the Empowerment Approach}

Even though I did not interview her first, I began my research with Jareth through contacting a case manager I will call "Shay." She was the only paid case manager in 2014 and was most familiar with the running of the actual organization and its programs. Shay said that she was eager to work with me because research was seldom taking place with Jareth. She hoped this research would help people have an appreciation for the situation of incarcerated women in the Illinois prison system and see how necessary organizations such as Jareth can be.

When I asked how Shay became a part of the organization, she told me a story of how she met two of the founding board members of Jareth while attending a Community Organizing class as part of her M.S.W. degree. At that time there were no paid staff, no funding, it was completely run by volunteers, and the board members were attending city council hearings in order to get the first Jareth house built. Shay explained to me, "I became involved in a class project at that point and I got butterflies in my stomach and my ears got really hot and I was like 'I need to work there!'.” While she admits that she was happily working with a domestic violence coalition for her M.S.W. 
internship, when she heard about Jareth she realized this was the "niche area" of social work she wanted to be part of. Shay continued to volunteer with Jareth through the remainder of her schooling but she told me that:

I kept asking if I could work there and [a board member] said, "We don't have any money yet." We got a little bit of money to hire a case manager and the board said, "You are a full time grad-student and working a full time internship. You do not have time."...The board gave me the job after I graduated and they didn't call anybody else because they knew I was obsessed with Jareth and they waited around until they could hire me.

Shay began as a case manager, working ten hours per week on grant writing, program coordination, and fundraising. Three and a half years later, she was employed as a fulltime paid case manager in the process of supervising five staff members, three interns, and two residential buildings.

\section{Unpacking Empowerment}

Having asked Shay to explain to me what Jareth is trying to accomplish through empowerment she stated,

We have to know, especially coming from jail or prison that someone has had their every move dictated most likely by white males that is not necessarily representative of the communities women came from. They have been told when they could eat and when they could go to the doctor and when they could go to sleep and when they could leave their cells. I see the empowerment side as teaching somebody that we feel, you know, what is best for you and we are going to help you get there. Instead of saying, like, "Okay you need to do this next," instead I feel like it is all from an empowerment standpoint. We are trying to empower women and educate our community.

This remainder of this chapter will focus on unpacking Jareth's

empowerment discourse. 
Shay stated, "There are definitely some road blocks specific to being a woman, and that's why I think it's important that Jareth was founded because there were no services specifically for women getting out of prison." Shay explained to me that these "road blocks" also apply to males in the criminal justice system also but that women experience them at much greater rates. Women are often primary caretakers or have custody of their children, have a history of unemployment or underemployment, are impoverished, have histories of drugs and/or alcohol use, physical and mental health issues, and histories of victimization by family members and intimate partners. According to Shay, compared to men, whose families often support them postincarceration, women are significantly less likely to receive housing and financial support from family and more likely to experience homelessness. The inability to find affordable and safe housing when first returning to the community places women at a greater risk for reoffending.

According to Shay, when women are released from incarceration, they must quickly attend to a variety of needs that are not met in prison. Jareth is designed to be a place for transitioning women to find assistance with these needs. She told me that she typically has a caseload range between thirty to thirty-five women a month and that the average participation time is about one year. The program looks for female identified ex-inmates that have made the individual choice to seek services within the organization and follow through with their commitment. "We're not a mandated service so sometimes people kind of just stop coming in and we can't chase them. We want to know that they want to be receiving our services," stated Shay. She further explained that sometimes 
clients stop participating for different reasons such as moving outside of the county, becoming stable and feeling like they no longer need services, or for unknown reasons.

I found it interesting that Shay felt the need to make it clear that this program was not mandatory. I argue that part of Jareth's empowerment discourse is about making a distinction between Jareth and the prison industrial complex/parole/probation offices. Prisons are both mandatory and non-voluntary which is a clearly defined power relationship. Parole/probation offices offer this same kind of dynamic where they are mandatory as part of an inmate's sentence if they do not want to spend their full sentence incarcerated. With one violation of the terms set by the correctional department and probation office, the inmate gets put back into prison for the remainder of their sentence. Presenting the program as one that is not mandatory and requires voluntary participation, attempts to separate Jareth from an unequal power relationship to more of a collaboration between case manager and client. While this has its own set of power dynamics that complicate the relationship, it is less obvious than the prison.

Shay told me that all or very close to all of the women both in the program and also within the prison system have some combination of sexual assault or domestic violence or abuse as a child. This makes a collaborative, non-mandatory relationship between client and case manager absolutely necessary. Shay told me that a common life narrative of a Jareth client is a woman who was assaulted at thirteen years old and did not feel as though she could tell her parents what had happened so she started selfmedicating, leading to a drug addiction, and finally to theft and prostitution in order to support her addiction. Now she has several felonies and has been in and out of prison throughout her adult life. "Somebody raped them at thirteen and that wasn't their fault 
and then all these other, I don't know, life factors - good and bad - end up kind of making that person who they are." Shay told me that she assumes her clients have been impacted by trauma at some point in their lives so when she works with clients she tries to understand how trauma affects the brain and problem-solving skills.

The need for a collaborative relationship between social worker and client makes sense in this context but it does make trying to understand the role empowerment plays in the organization more complicated. Shay's goal as a case manager is to ensure some kind of stability for her clients throughout their time with the program. She has to put herself in a position where she must push women towards completing goals that will make finding employment, housing, and other forms of stability easier to maintain, but at the same time, does not coerce her clients into a course of action they are not comfortable with. This is a complicated power dynamic. On the one hand, she is knowledgeable about resources in the community and is imparting this on to her client. On the other, Shay is in a position of power over these women by deciding what is and is not the best plan for them without ever having been in their position herself. Is this really empowerment? Shay, "sees the empowerment side as teaching somebody that we [Jareth] feel like you [client] know what is best for you and we are going to help you get there." But, she says at another point in our interview that she is, "letting people know what our clients are going through without them having to say it or break their confidentiality, it would be most empowering if they were speaking for themselves, but we are advocating for them and have their best interest at heart, and care what happens to [clients]." If it is more empowering for these women to advocate for themselves then why are white, educated women and men speaking and why do they have the power to empower? 
Going back to the previous statement made by Shay, "I see the empowerment side as teaching somebody that we feel, you know, what is best for you and we are going to help you get there," there is still an underlying tension in this thinking. Shay is working with recently incarcerated women, many of whom she admits have significant histories of substance abuse, trauma, and mental health issues. These women were tried and convicted for crimes that resulted in jail or prison time. While I am fully aware that there are larger systemic inequalities and racialized targeting of offenders that goes into who gets arrested and convicted in the United States criminal justice system, it is also pertinent to note that these women, partly because of their histories and recent incarceration, may not have the greatest judgement or necessarily know what is best for themselves at this point in their lives. While I argue that it is empowering to collaborate rather than impose the social worker's will on the client, there is something to be said about both being acutely aware of the client's position that fuels the complicated power dynamic of the social-worker/client relationship. Even though Jareth says that the relationship is collaborative, they are only helping to empower women, on a pragmatic level, there is a lot of telling women what they need to do and that isn't necessarily a bad thing. It is what many women need and are looking for on a pragmatic level.

I argue that part of Jareth's empowerment discourse is helping women achieve independence by instilling notions of appropriate and inappropriate forms of dependence and power: certain notions of what is and is not dependence. Appropriate forms of dependence include social services such as Jareth and drug and alcohol rehabilitation programs because they are temporary. Eventually, women are supposed to be 'independent' which actually means dependence on wage labor and other parts of the 
welfare state. According to the logic of Jareth, dependence is initially okay if it leads to later independence. In other words, there is power in being able to take care of oneself in a productive way rather than relying on the support of others. According to Jareth's empowerment discourse however, becoming dependent on family members or the state for one's living is not empowering and is an inappropriate form of dependence. Jareth's own mission is to reduce recidivism, meaning that their goal is to transform women's dependence on the state (being in prison) to becoming independent citizens.

This kind of thinking about dependence and independence is pragmatic. How else do you deal with homelessness, unemployment, and other needs if they are not being addressed prior to incarceration or while incarcerated? If someone needs money to pay rent for an apartment, then you tell them they need a job and show them how to get it: there is power in this. However, this discourse implies that women were not empowered through their crimes. Piper was quite "empowered" when she was shoplifting and forging prescriptions, for instance, as she was supporting her family and generating a livable income. Jareth's discourse of empowerment then relies on giving women a kind of power that allows for independence but through employment rather than crime which makes a clear distinction between appropriate and inappropriate forms of power.

Shay explained to me that one of the barriers that women face is the popular idea that prisons provide training and rehabilitation services to women that empower them, or help them to earn a legitimate living once they are released. Shay told me that part of Jareth's empowerment discourse includes educating the community through rebutting the popular idea that ample education programming exists in prisons. Just because there are different types of job training such as computer training and various trade certificates, 
does not mean that women will be prepared for life outside prison walls. Shay explained that the reality is more complicated: education and job training exists but it continues to be cut from corrections budgets and the classes fill up fast when they are offered, so that they are not available to everyone. She used the example of a career tech prison program that is offered in one of the women's prisons. The program provides the basics of resume building, techniques for interviewing such as successfully talking about one's background, and how to present oneself to professionals. If the class is full when the inmate enters prison, and then gets out the next month, they are out of luck. The instructor could also be on vacation or maternity leave and so the class may not be offered for periods of time. Also, the length of one's sentence determines eligibility for GED classes and certificate programs. This means that the shorter the sentence, the less eligible the inmate is for educational and vocational opportunities. Shay did explain to me that some women "have made the best out of their time there and got a lot of certificates in like cooking, safety, and sanitation, and they've really used that to leverage a better career for themselves" but the reality of it is that most women are coming out of prison ill-prepared. Furthermore, being ill prepared for getting a job means that it becomes incredibly difficult to support oneself when back in the community. If a woman is on probation or parole and has additional mandated requirements set by these services, failure to find suitable income, housing, and treatment (if needed) could mean violation of parole and the possibility of additional prison or jail time.

If empowerment is also about resolving this existing mindset amongst the community about education and vocational training in prisons, then empowerment is more than just about the individual former inmates. This is an important point to be made 
in a culture that stresses individualism rather than political solidarity. In other words, for Jareth, part of empowering women being released from prison is increasing their opportunities by trying to convince other people that they should give former inmates jobs.

Empowerment can be used as a political tool and I argue that through educating the community about these issues, Jareth is taking a political stance that says prisons and community perceptions of criminalization need to be reformed. While Jareth utilizes much of its resources in providing services to their clients, community education and advocacy can go a long way in transforming communities and breaking down some of the barriers that recently released inmates are forced to navigate. For example, staff often give presentations at local colleges, city council meetings, and to businesses around the area focusing on debunking the myth that there is a typical female felon and that she can be picked out of the crowd because of some obvious physical characteristic. However, these presentations also paint former female felons as powerless victims rather than hardened, violent criminals, so that communities are more likely to help rather than shut out former inmates from needed resources such as jobs. This may not be empowering for the women themselves as it reinforces gendered ideas of women as always-already powerless and inherently victims but again, it transforms community perceptions. These presentations focus also on making explicit the conditions of Illinois prisons, the lack of resources available throughout the state and more specifically in the community, and encourages city leaders and businesses to open up their arms to former felons. This kind of community advocacy is effective in beginning to change the perceptions of the community. The YWCA in the area has agreed to merge with Jareth as a means to 
increase each organizations available services to women and there has been talk about city funding a micro-business that is run by former inmates.

That being said, much of the empowering work being done at Jareth involves dealing with clients that have already been through the criminal justice system and are now dealing with its inadequacies and failures. It can be argued that women are coming out of prison worse off than when they entered because prison isolates women from their families causing fractures in their support system, are often the victims of sexual assault by staff, suffer from inadequate physical and mental health care, and leave prison with little to no money and yet little reform to the prison industrial complex is happening. The work is then placed on social service agencies in communities to try to help in pragmatic, feasible ways such as job training in order to help repair some of the damage caused by the system itself. Even then the task of helping these women is very hard. As Piper's story shows, even with college degrees and prior experience, she has an incredibly difficult time finding employment. The only reason she is even surviving at all without the help of Jareth is because she gets monthly disability checks that cover basic expenses and then she relies on family members to help where they can. Empowerment can only go so far as a strategy for helping women. Realistically, if the United States focused on the significant problems that exist within the economy, health care, education, and even prisons themselves rather than incarcerating non-violent and racialized offenders, building more prisons, and creating ever-tougher laws than much of the work being done by Jareth would not be needed. 


\section{CHAPTER IV \\ EMPOWERMENT AS GOVERNMENTALITY \\ Introduction}

This chapter is concerned with how logics of empowerment and practices of subjectification are linked together. I argue that Jareth's empowerment discourse reflects an important shift in the reconfiguration of governmental methods that gives women specific power, professionalism, which is expected to be used through selfregulation within the market. This chapter explores the ways in which Jareth helps women to gain power, how women are expected to use this power, and how strategies of empowerment meet political goals of neoliberal governmentality.

Empowerment, through the power of professionalism, can be a kind of governmentality where the individual is expected to self-regulate and engage appropriately in the free-market.

\section{Unpacking Professionalism}

I had found out within the criminal justice department that a graduate student, who I will call Carl, had previously interned with the Jareth during his summer break. Open to chatting with me about his experiences with the organization, we set up a time to meet at the university. Carl told me he was in his late twenties, white, middleclass, and in his second year of his master's degree. He had access to the criminal justice department conference room and thought it best we spoke there. Dressed in a casual 
sweater and jeans, he engaged me in small-talk about the progress on his degree while showing me into the generic conference room.

Carl told me that he had imagined, because he was told that this position was needed, that he would help with grant-writing for the organization. "What ultimately happened was that when I got there they were getting ready to start a vocational training program for women" and they recruited him to help with this program instead. This was the first time that Jareth ran this program so the organization of each class was initially unknown. Shay began the program after working with the women of Jareth for several years and determined that this kind of program would be beneficial as employment was an issue for a majority of the women. Explaining the larger program goals, Carl stated,

We wanted to provide them [clients] with some sort of certification that said, 'This is what I did, this is what I learned' We knew that obviously some places weren't going to acknowledge that as being legitimate, but we thought that if we could show them that, you know, this person did X amount of hours learning about this and that they had good attendance that something like that would show potential employers that they have some necessary skills.

Because giving formerly incarcerated women credibility and employability was the ultimate goal, he had hoped that when the women entered the workforce that they would have something positive that would help employers overlook their criminal record.

Carl, Shay, and an additional staff member spent three weeks prior to the start of the vocational class planning daily activities, recruiting speakers, and determining the rules of the program. Having no previous experience running this kind of class, the staff had little to draw from, but Carl told me that Shay was familiar with six of the twelve women who would be participating which made planning out classes that would meet their needs a bit easier. The program was designed to feel like participants were 
employed, meaning that the class ran anywhere from six to eight hours a day, three days a week, for eight weeks, and daily attendance was required. Carl explained that part of making the program feel more like a job included paying members of the class a stipend as part of the financial literacy goals of the class. "I can't remember exactly how much," he said, "but they were paid once a week and it was neat how we set that up." They partnered with a local credit union and participating women were set up with savings accounts. For some this was their first bank account ever. "We had a stipend set up through our grant funding," Carl told me, “we didn't want to just give them cash because we didn't want them to just turn around and do whatever with that cash. We wanted to make it a little bit more relative to how a job would work."

Jareth's empowerment discourse, more specifically engaged in the last chapter, and the vocational class are linked in that they help women gain a specific kind of power in the form of professionalism. The ability to be seen as professional and thus, employable, is a form of power. Framing professionalism as "common-sense" Carl told me that, "The general expectation was for them to treat it like a job, to treat the program like a job." This meant for him that they needed to show up, be both mature and respectful around those presenting, and to avoid treating other class members like friends. I want to now unpack Jareth's discourse of professionalism in order to better understand how women are gaining power.

Professionalism is an interesting type of power to help women gain in this context and one that needs to be explored further. There is power in being able to convince someone that you are trustworthy and reliable and thus able to be employed. Why this type of power? I argue that these women were already powerful in that they 
resisted gendered ideas of appropriate femininity through committing crimes, have actively disobeyed the state by breaking the law, and also through having a criminal record these women are perceived as second-class citizens in that they lose certain rights such as voting and owning a gun. There is power in resisting hegemonic masculinity and also the state and yet part of this empowerment discourse is to construct that these women are actually disempowered and then teach them how to employ a more appropriate form of power by encouraging these women to be professional, and to then use their energy to find employment.

Jareth has found that more masculine-normative employment such as labor and trades jobs are more willing to accept a criminal record and still provide a livable wage. Health and education fields are heavily female-dominated but those same fields do not hire women with felonies and as such are not an option. Minimum-wage jobs have become increasingly difficult to attain with a criminal record and do not pay enough to support a family. Minimum-wage jobs include service-oriented jobs such as fast food and serving or cooking at restaurants, entry-level retail jobs, and others within the entertainment industry including concessions at the movie theater, ride-operators at local amusement parks, and other similar jobs. There exists a separation here between these minimum-wage jobs and trades and labor jobs. The vocational class focuses on career paths within trades and labor such as welding, construction, electrical work, plumbing, and other similar careers which are heavily male-dominated and also part of the working-class.

There is a relationship regarding the intersections of gender, class, and professionalism in this context. Jareth has set up a vocational class that is designed in part 
to educate women on possible job opportunities they may have not considered prior to being incarcerated. Shay explained,

We've made it a point to have a class on exposure to trades and labor jobs for women. They may not have ever thought about this and I know I never thought about like being an electrician even though my parents raised me to see that women can do anything that men can do. So our clients will meet female electricians and are like "I didn't know women could do that!" The female electricians are so cool and want more women on the job sites.

First, there is a gendered aspect to this as women are generally not thought of in terms of these jobs and also women themselves are not seeing trade and labor jobs as an option. Second, these jobs are offered as an option because of each participant's current status as a felon and not because she is a women and should be represented in these fields. Further, trades and labor jobs are not "professional" jobs such as those in law and corporate business. They are working-class jobs so Jareth's discourse about professionalism creates an interesting classed tension in this case where women are directed towards a certain class of job but socialized to meet the needs of jobs they cannot apply for because of their record and status as working class. If women are encouraged to pursue these workingclass jobs why then is the major focus on professionalism?

There is an argument to be made about gender, criminalization, and power here. Women are encouraged to search for employment outside of female-dominated fields when they have resisted hegemonic notions of femininity, through committing crimes because it benefits both the economy and the individual. However, because these same women are resisting these notions of femininity it is necessary then to push them to be more professional which includes being submissive, respectable, trustworthy, etc. because when women commit crimes they are cast as untrustworthy, aggressive, and 
disrespectful. The tension here is that they are pushed to be more professional in order for them to be hired but they are applying to working-class jobs where professionalism may not be appropriate.

What is interesting is that while these women are being pushed towards working-class jobs through meeting other women in the field, training to be welders and electricians, and learning other job skills, the program also does other "empowering" activities. Carl explained to me that the program ended up doing a wide range of activities. The group often met in the basement of a local church if the activity did not require the group to be at a specific location. Framing these activities as ways to build up self-esteem, the women would be led in journaling, bracelet-making, group-therapy exercises, and other activities that could be categorized as therapeutic. Carl stated,

It was hard to balance everything because there was a lot of sensitive issues. This is Jareth but we aren't necessarily doing case work and we wanted to limit that but also not deprive them of the opportunity to share. There were times whenever we would do group journaling where it would be less professional and more about circumstances of their lives and the impact of incarceration. But mostly we expected them to treat it like a job. We don't want to suppress it but we wanted to make sure that they understood that this was maybe not the environment for that.

This is an important point to be made. The women who participated in this class came from a background of mental and physical illness, trauma, abuse, and substance dependence among other things. This does not even include the additional trauma that is added on from the prison experience itself. From the rampant sexual assault by correctional officers, the inhumane living conditions in some facilities, the lack of good physical and mental health care as well as treatment for substance abuse, and the years spent away from their family and other support systems adds up and really effects inmates and ex-inmates. While Jareth does not consider itself an organization that is 
overtly therapeutic, the staff are well aware that these women need these services. What becomes interesting then is how these "empowering" activities got thrown into a vocational training program where women were expected to be professional and treat the class like a job. This demonstrates the significant debilitation that ex-inmates are forced to deal with before, during, and after incarceration in which makes daily professionalism an expectation that is impossible to achieve but also that journaling activities are unprofessional as part of professionalism includes keeping your private life out of your work life.

Unpacking professionalism further, Carl recounted that half of the women were involved with another person during the class and, "it just created too much tension”. In the beginning it was a bit of a scramble to get participants so he explained that they had overlooked or maybe could not have predicted the extent of problems that would occur by inviting couples to join the program. "There were concern with things like are we going to be in class and are they going to be all over each other, or in public, and will this carry over into work, like, will they be professional if they are with their partner?"

Looking at the demographics of this class, six of the twelve women participating were actively in relationships with one another. This means that half of the class were not merely friends but in sexual relationships with one another. Among these six women in relationships, Shay was only familiar with three of their backgrounds and the other three were recruited by their partners already planning to participate. If the class was supposed to be about learning how to become employable, and thus professional, and that part of this professional discourse includes not being friends with one another, than 
why did Shay and the other staff members recruit women they knew were in relationships? I would argue that when working with ex-inmates in a social service agency, it is difficult to separate professionalism from service.

Carl stated that part of professionalism included being mature and also respectable towards people in the community such as speakers. Shay also stated in a later interview with me similar sentiments, for example, that "This [class] is practice for a job, so don't come in your pajamas and slippers... when we are at job sites with volunteers we have to take them aside and remind them that they are representing Jareth so don't yell out 'aww my fucking crotch itches'". This in part goes back to appropriate femininities but also to what is acceptable behavior in working-class versus professional jobs. There are few jobs that would allow anyone to come to work in pajamas and slippers and the expectation that these women not come to class in pajamas is not unreasonable. However, there is a power in being able to openly express concern about one's genitals in the sense that women are encouraged to avoid talking openly about their bodies. There is power in resisting body-policing. While it is still in one's best interest to avoid this kind of behavior around coworkers and other people in the community, it is important to distinguish what kinds of power are encouraged and those which are not.

After my interview with Carl, I spoke again with Shay about this particular vocational program as she also participated as a staff member both during the first time the class ran and all subsequent classes. We met at a local training facility where two ex-inmates were being trained in forklift operations. Taking me to a nearby classroom, I could hear the sounds of forklifts and the voice of the male instructor as we 
spoke. Shay told me that their program had changed quite a bit since the time that Carl supervised it.

We had meetings at the end of last round and thought about what we wanted to do differently in the future... We used to offer a stipend and it would kind of teach people how to budget and we would kind of get them a check as part of the grant and we found a lot of people would take it for the wrong reasons and clearly didn't want to be there and instead were just trying to get some spending money.

Regarding the stipend money, it is rather interesting how Shay seems to be policing the motivations of the women, by criticizing the 'right' and 'wrong' reasons for taking the class. It seems perfectly reasonable that women would take the class for the spending money. Most people only work in order to make money so why should these women feel or do any different? The goal of the program is to help these women get employed and this class does take up a large portion of their day. Ex-inmates are not coming out of prison with a livable income and job waiting for them, so if there is a program that is educational it is not unreasonable to also offer some kind of cash compensation in order for these women to survive until they become employed. That being said, part of professionalism is to pretend to enjoy the job you are doing, show devotion to that job, and to also be very good at it. Shay wanted to believe that the women in the program were completely devoted to the class because it benefited them in finding future employment. As she stated, she believed the women were doing it for the wrong reasons - in this case spending money. This exemplifies logic associated with professionalism where you pretend to enjoy your job even though at the end of the day it is for a paycheck. 
Jareth has since found funding for a program where women can participate in vocational training that, instead of offering a stipend, pays for OSHA and forklift training certification. Held twice a year for 8 weeks, this program exposes women with a criminal background to trades and labor jobs that pay more than minimum wage and provides them with the necessary certifications to get hired. Several changes have been made for this class based on how the last vocational training program taught by Carl went. A rule change has been added to the screening process where no woman with a battery or assault charge less than a year old would be allowed to participate.

We realized that anyone that wasn't able to successfully participate in a group last time and maybe had to be asked to leave, a lot of that was they had a battery or assault charge from not that long ago and it was too new for us to know if they figured out how to solve their problems.

Additionally, participants need to be able to earn their G.E.D. and get their driver's license within one year in order to participate, as many trade jobs require these items.

We stress more this time that you have to be able to attend every session too. I think we were too lax with that the first time and especially with forklift and OSHA there is a certain amount of hours you have to put in and if you miss that hour you have to make it up.

This program, while similar to the first vocational class with Carl, takes

into consideration not only that women can get employed more easily in trade and labor jobs with a criminal record but makes it so women are now qualified to work in these fields. Many jobs within trade and labor require OSHA certification and forklift training is an added bonus that opens up more opportunities for these women. The major difference between this program and the last is that the empowering self-esteem activities such as journaling and bracelet making have been removed and the focus is completely on job skills. Further, women must display a certain amount of professionalism in order 
to participate. This is exemplified in the rule changes that followed the last program.

Participants are expected to be able to work with one another without violence which is an important part of both getting and keeping a job. Participants must also demonstrate devotion to getting a job in this field by having good attendance and willingness to meet all minimum qualifications (G.E.D. and drivers license) so that they can leave the program ready to begin the job application process. Removing self-esteem activities makes it clear that dealing with trauma, experiences of incarceration, and mental health means that either participants deal with these things outside of this class or not at all and also that these activities are not seen as part of professionalism.

Largely as a result of the inability for some women to handle the intensity of the previous vocational training class, Jareth now offers an additional program that incorporates a soft-skills curriculum. Shay cites problem-solving skills as a major struggle for some women that has become a main focus during the soft-skills classes. For example, she sees a lot of attendance problems because the client didn't have childcare to the client it appears legitimate that if the babysitter calls off, you don't come to work. Shay wants to incorporate pre-planning skills that help women to create backup plans for childcare or an arrangement with her employer in case of a crisis. Shay explained,

Seeing one-step in front of you when people have always been in crisis, they only see the first step and that is as far as they have been able to get...so soft skills are a lot of not like tactical tools of how to do the job but how to be a good employee, how to be on time, how to plan, what time to get up, what time to be ready by to get on the bus and then how long that takes to get to work, it's not just show up and you do your job, you have to not bring your personal baggage and emotional baggage...a lot of our clients can get jobs but they can't keep them. 
In other words, a soft-skills curriculum means that women are lacking professionalism so it attempts to educate and help women develop professional behaviors so that they can participate in the more intensive vocational program or find a job.

So then how does Jareth expect women to use professionalism? Jareth provides job training and educates them in professionalism so that they can leave Jareth services with a steady job that allows them to be self-sufficient. Professionalism is a kind of power and the job is the result of using this power. As argued above, criminal women also have power in their marginalization that can be used as a starting point for resistance. Jareth, however, wants to negate this kind of power with a different kind of power, professionalism, in which the ex-inmate transforms the self from a criminal to a hardworking, employed, appropriate, self-sufficient woman that fits into the larger aggregate of law-abiding people. This kind of power is pragmatic both for the organization and the individual in that this path leads to comfort, reduced chances of re-incarceration, stability for the individual, and funding for the organization. But as engaged in the previous chapter, Jareth's empowerment discourse expects the ex-inmate to avoid acknowledging how the criminal justice system and the state structurally limits options for felons. Those who do not participate with Jareth are free to engage in alternative power battles. For Jareth, power is expected to be used in particular ways that transforms how their criminal status is perceived by others which does help women pragmatically but limit alternatives and possibilities for change.

What is interesting about using empowerment as a strategy to help women become more professional is that even though staff have expectations about how the women should behave, what goals they should be working towards through self- 
regulation and employment, Jareth expects all of this to be through voluntary submission. Jareth is not forcing anyone to attend these classes. There has to be a certain mindset of wanting to engage with services before Jareth can help. In a sense, the external surveillance of prison that supposedly reforms women into moral subjects is then turned inwards where they become their own kind of investor. Thus, "women are convinced to participate in their own empowerment without threats, governance in this case, is something we do to ourselves, not something done to us by those in power" (Cruikshank 1999, 17). This is a kind of subjectification where subjects volunteer themselves, which allows for a feeling that there is active agency and choice but actually opens them to less obvious modes of coercive subjectification. What this means is that Jareth could encourage women to use the power they already possess as felons but instead encourage women to develop themselves professionally as a form of power that aids them in employment. Because women are choosing to seek services, participate in these classes, become qualified in certain job skills, and eventually get a job it would appear as though this was all very individualized. By helping women get jobs and ensuring that they choose this for themselves, it does not feel like the same kind of state control as seen within prisons where women are forced to reform or spend additional time in prison. However, even though this may not seem like a kind of subjectification because of its utility and pragmatic nature, there is still an end goal that furthers neoliberalism and the free-market. Pongratz (2011: 161-172) explains,

What is demanded is not just an economically calculative self-relationship, but the constant demonstration of self-responsibility, private-care, and self-managed prevention. In this context, under-socialized-that is, workshy, prevention-refusing, activation-resistant-subjects constitute threats to the social-economically, as investment failures, and morally as beneficiaries of solidarity. 
In other words, discourses of empowerment that encourage professionalism are a calculated self-relationship where you must constantly demonstrate that you are able to provide for yourself without the aid of the state. Those who are under-socialized, in this case unprofessional and non-self-regulating individuals, constitute a threat to the social and economic system as burdens of the state who will continue to be re-incarcerated. Empowerment through professionalism is really then just a new kind of technology of governance as a way for women to gain self-esteem, self-sufficiency, and responsibility self-regulation - while pushing women towards traditional paths such as employment which is benefits the system in place but does not offer any means of alternative uses of power or systems. So while empowerment may seem pragmatic and benign, there is an underlying power dynamic that meets the goals of neoliberal subjectivities. 


\section{CHAPTER V \\ SUMMARY, CONCLUSIONS, AND ALTERNATIVES \\ Summary and Findings}

Through the exploration and unpacking of Jareth's empowerment

discourse, several conclusions can be gleaned. First, empowerment is a concept that, while understood differently depending on the institution and context, is incredibly complex. I went into this research wanting to learn more about the experiences of women in the prison industrial complex through a social service organization that aims to help women transition from prison to the community. With one confusing statement from Shay about utilizing empowerment as a framework for helping these women, I became fixated on questions of empowerment that would end up being the bulk of my research.

Empowerment has become a buzzword that carries overly-positive connotations. Often I find that empowerment is seen as such a positive modality that it is almost taboo to question its worth. And yet there I sat amongst pages of transcribed interviews questioning whether empowerment really was as great as it appeared. Because its goal is giving power to those who are disenfranchised, it seems problematic to question the concept. While I too support the goals of enfranchisement, I question what kind of power is envisioned, and who ultimately benefit from this power. I question whether empowerment prohibits the utilization of alternative forms of power 
My research showed that Jareth's empowerment discourse was effective at helping some women find employment but is limited by employers' discrimination against felons. I found that prison training programs are often inaccessible to women and rarely prepare women for reentry.. When working with recently incarcerated women in need of shelter, a livable income, and ultimately independence, it is pragmatic to instruct these women on how to get and keep a job and to help them develop a plan for housing and for staying out of prison in the future. However, this is only effective to a certain degree due to barriers that exist within the community.

By investigating Jareth's vision and mission, and the approach of its staff, I found that empowerment signified a particular kind of appropriate power and dependence. Appropriate forms of dependence include temporary social services such as Jareth and drug and alcohol rehabilitation centers. Eventually, women are supposed to be "independent" which actually means dependence on wage labor and other parts of the welfare state. According to the logic of Jareth, dependence is initially okay if it leads to later independence. In other words, there is power in being able to take care of oneself in a productive way rather than relying on the support of others. Jareth's empowerment discourse however sees becoming dependent on family members or the state for one's living as not empowering and an inappropriate form of dependence.

Notions of inappropriate and appropriate power also apply. There is power in the capacity to rent an apartment. But women were also empowered through their crimes. Piper was quite 'empowered' when she was shoplifting and forging prescriptions, for instance, as she was supporting her family and generating a livable income. Jareth's discourse of empowerment then relies on giving women a kind of power that allows for 
independence through employment rather than crime which makes a clear distinction between appropriate and inappropriate forms of power.

Third, I found that Jareth is re-articulating what power means through an 'empowerment' discourse that casts women as powerless victims. As Jareth attempts to increase opportunities for their client they must onvince employers to give former inmates jobs. Therefore, by casting women as powerless victims rather than hardened, violent criminals, communities are more likely to help rather than shut out former inmates from needed resources such as jobs. This may not be empowering for the women themselves as it reinforces gendered ideas of women as always-already powerless and inherently victims but again, it transforms community perceptions.

Empowerment could be used as a political tool through educating the community about these convicted women's issues. Jareth is indeed taking a political stance that says prisons and community perceptions of criminalization need to be reformed. While Jareth utilizes much of its resources in providing services to their clients, community education and advocacy can go a long way in transforming communities and breaking down some of the barriers that recently released inmates are forced to navigate.

Fourth, I found that empowerment and practices of subjectification are linked together in that Jareth's empowerment discourse reflects an important shift in the reconfiguration of governmental methods that gives women specific power, professionalism, which is expected to be used through self-regulation within the market. Jareth helps women to gain power and use power in particular ways. Jareth helps women gain trustworthiness, reliability, and respectability through professionalism that gives women the power to attain employment. However, due to their criminal record many of 
the female-dominated fields such as healthcare and education are off limits to felons and therefore Jareth helps women get jobs in the trades and labor field such as construction, plumbing, and electrical technicians which are male-dominated. Women are encouraged to search for employment outside of female-dominated fields when they have transgressed or resisted hegemonic notions of femininity, through their crimes, because it benefits both the economy and the individual. However, because these same women are resisting these notions of femininity it is necessary then to push these same women to be more professional which includes being submissive, respectable, trustworthy, etc. which the criminal status had negated, in order for them to be hired in a field where professionalism may not be appropriate in working-class jobs. Women are then expected to use a more appropriate form of power, professionalism, to get jobs rather than using other forms of power they already possess through the process of criminalization and marginalization.

Fifth, my study shows that strategies of empowerment meet political goals of neoliberal governance. Jareth requires that its participants voluntarily submit themselves to their services as part of the process of empowerment. By helping women get jobs and ensuring that they choose this for themselves, Jareth does not present as the same kind of state control as seen within prisons where women are forced to reform or spend additional time in prison. However, even though this may not seem like a kind of subjectification because of its utility and pragmatic nature, there is still an end goal that furthers neoliberalism and the free-market. Discourses of empowerment that encourage professionalism are a calculated self-relationship where you must constantly demonstrate that you are able to provide for yourself without the aid of the state. Those who are 
under-socialized, in this case unprofessional and non-self-regulating individuals, constitute a threat to the social and economic system as burdens of the state who will continue to be re-incarcerated. My study shows that empowerment through professionalism is primarily a technology of governance that foster's women self-esteem, self-sufficiency, and responsibility - and ultimately their self-regulation - making employment and temporary dependence on social services the only means of appropriate power.

\begin{abstract}
Alternatives?
While it is beyond the scope of this research to offer alternative treatment modalities within the prison industrial complex I do think it is pertinent to reiterate that despite the use of empowerment and other therapeutic techniques Jareth tries to use to help these former inmates, Piper, considered a stable Jareth client, is only surviving successfully on her own because she is getting a monthly disability check from the government. She was unable to find employment because of her criminal record despite being qualified, having college degrees, and despite her previous work experience.

While Piper is among one of many released inmates trying to navigate daily life with a record, the criminal record is not the only barrier that is a problem. While removing the requirement to notify your employer of a felony could disrupt force of discrimination and provide non-violent ex-offenders with a opportunity to work, such a program would not remove the debilitating and traumatic effects of incarceration or the trauma, mental illness, and substance abuse that is so common among female inmates prior to incarceration. Prison is not meeting the needs of its inmates and therefore women are coming out ill-prepared to deal with daily struggles. I would like to offer the
\end{abstract}


suggestion that we treat prison as a disability and offer monthly disability checks as a source of income to former inmates.

I imagine that this suggestion would lead to cries of outrage from the general public about choice, responsibility, and deservingness that comes along with criminalization but the rate at which former inmates are re-incarcerated for committing old and new crimes as a source of survival because of how difficult it is to navigate the community with a record, the cost of incarceration itself is crippling the economy. It would ultimately be more cost-effective to pay a monthly income to former inmates.

This would decrease the debt and numbers of those incarcerated in the United States and would finally acknowledge how detrimental prisons are to those confined and to the country itself. If this seems like an unrealistic alternative than I would suggest that the United States acknowledge existing structural inequalities and improve health care, education, poverty, the economy, and the criminal justice system which would also decrease the numbers of people imprisoned, the costs associated with this, and relieve organizations such as Jareth of having to help increasing numbers of former inmates navigate the community - but this seems as far-fetched as the first. 


\section{REFERENCES}

Beckett, Katherine, and Bruce Western. 2002. "Governing Social Marginality: Welfare, Incarceration, and the Transformation of State Policy." Punishment \& Society 3:43- 59.

Belknap, J. 2001. The Invisible Woman: Gender, Crime and Justice. Belmont, CA: Wadsworth.

Bransford, Cassandra. 2011. Reconciling Paternalism and Empowerment in Clinical Practice: An Intersubjective Perspective.” Social Work, 66(1): 33-41.

Carson, Ann E. 2015. “Prisoners in 2014”. Bureau of Justice Statistics.

Chesney-Lind, Meda. 2013. The Female Offender: Girls, Women and Crime. Thousand Oaks, CA: Sage Publications.

Chesney-Lind and Mauer, Marc. 2002. Invisible Punishment: The Collateral

Consequences of Mass Imprisonment. New York: The New York Press.

Conger, Jay A. and Kanungo, Rabindra N. 1988. The Empowerment Process: Integrating Theory and Practice. Academy of Management Review. 13(3):471-482.

Cruikshank, Barbara. The Will to Empower: Democratic Citizens and Other Subjects. Ithaca:Cornell University Press. 1999.

Davis, Angela Y. 2003. Are Prison's Obsolete? New York: Seven Stories Press.

Drybread, K. 2014. "Murder and the Making of Man-Subjects in a Brazilian Juvenile Prison." American Anthropologist 116(4).

Foucault, Michel. 1977. Discipline \& Punish: The Birth of the Prison. New York: Random House Books.

Foucault, Michel. 1980. Power/Knowledge: Selected Interviews and Other Writings, 1972-1977. New York: Random House Books.

Foucault, M. 2007. Security, territory, population: Lectures at the Colle`ge de France, 1977-1978. (G. Burchell, Trans.). Basingstoke: Palgrave Macmillan. 
GlenMaye, Linnea. 1998. "Empowerment of Women." In Gutierrez, Lorraine, Parsons, Ruth and, Enid Opal Cox (Eds.), Empowerment in Social Work Practice: a Sourcebook.

Gutierrez, Lorraine, Glenmaye, Linnea; and Kate Delois. 1995. The Organizational Context of Empowerment Practice: Implications for Social Work Administration. Social Work 40:2.

Gutierrez, Lorraine M.; Parsons, Ruth J.; and Cox, Enid Opal. 1998. Empowerment in Social Work Practice: A Sourcebook. Pacific Grove, CA: Brooks/Cole Publishing Company.

Hattery, Angela and Smith, Earl. 2010. Prisoner Reentry and Social Capital: The Long Road to Reintegration. UK: Lexington Books.

Jacobs, Ann. 2001. Give 'Em a Fighting Chance: Women Offenders Reenter Society. Criminal Justice Magazine 45.

Koski, Susan and Costanza, S.E. 2015. "An Examination of Narratives From Women Offenders: Are Gender-Specific Reentry Efforts Needed? Qualitative Sociology Review 11(1): 70- 89.

Labotka, Lori. 2015. "Healthy, Beautiful Hair: Cultivating the Self in a Women's Prison" (Dissertation). University of Arizona.

Owen, Barbara. 1998. In the Mix: Struggle and Survival in a Women's Prison. New York: State University of New York Press.

Pongratz, Ludwig A. 2011. "Controlled Freedom - the Formation of the Control Society." Pedagogicky Casopos 2:161-172.

Richie, Beth E. 2012. Arrested Justice: Black Women, Violence, and America's Prison Nation. New York: New York University Press.

Simon, Barbara Levy. 1994. The Empowerment Tradition in American Social Work: A History. New York: Columbia University Press.

Soloman, Barbara B. 1976. Black Empowerment: Social Work in Oppressed Communities. New York: Columbia University Press.

Rapp, Charles, Shera, Wes, and Kisthardt, Walter. 1993. "Research Strategies for Consumer Empowerment of People with Severe Mental Illness." Social Work: 38: 6. 
Spade, Dean. 2011. Normal Life: Administrative Violence, Critical Trans Politics, and the Limits of Law. New York: South End Press.

Waldram, James B. 2012. Hound Pound Narrative: Sexual Offender Habilitation and the Anthropology of Therapeutic Intervention. Berkeley: University of California Press.

Young, Vernette D., Reviere, Rebecca. 2006. Women behind bars: Gender and Race in Prisons.Boulder: Lynne Rienner Publishers. 